\title{
Article
}

\section{The Impact of Sargassum Inundations on the Turks and Caicos Islands}

\author{
Debbie Bartlett ${ }^{1, *}$ and Franziska Elmer ${ }^{2}$ D \\ 1 Central Avenue, Faculty of Engineering \& Science, University of Greenwich, Chatham Maritime, \\ Medway ME4 4TB, UK \\ 2 Center for Marine Resource Studies, School for Field Studies, \\ Cockburn Harbour TKCA 1ZZ, Turks and Caicos Islands; franziskaelmer@hotmail.com \\ * Correspondence: D.Bartlett@greenwich.ac.uk
}

check for

updates

Citation: Bartlett, D.; Elmer, F. The Impact of Sargassum Inundations on the Turks and Caicos Islands.

Phycology 2021, 1, 83-104. https:// doi.org/10.3390/phycology1020007

Academic Editor: Juan J. Vergara

Received: 20 August 2021

Accepted: 28 October 2021

Published: 2 November 2021

Publisher's Note: MDPI stays neutral with regard to jurisdictional claims in published maps and institutional affiliations.

Copyright: (c) 2021 by the authors. Licensee MDPI, Basel, Switzerland. This article is an open access article distributed under the terms and conditions of the Creative Commons Attribution (CC BY) license (https:// creativecommons.org/licenses/by/ $4.0 /)$.

\begin{abstract}
Since 2011, holopelagic Sargassum fluitans and natans have been arriving en masse to the wider Caribbean region and West Africa, impacting near-shore habitats and coastal communities. We examined the impacts of the Sargassum influx on tourism-related businesses through face-to-face interviews and focus groups and on near-shore seagrass beds through in-water surveys in the Turks and Caicos Islands (TCI). Substantial accumulations of sargassum were found on the beaches of South Caicos and Middle Creek Cay in 2018 and 2019, including a Sargassum brown tide in 2018. A variety of different approaches to removing sargassum from the beaches were mentioned and a desire from local businesses as well as local authorities to find a sustainable, cost-effective solution to what is viewed by many as a serious problem. The brown tide and sargassum accumulating as a layer on the benthos inside the seagrass beds caused significant loss of Thalassia testudinum. Halodule wrightii, macroalgae and sand plains were found in the areas lost by T. testudinum. This finding suggests that, if a cost-effective end use for sargassum could be identified, harvesting material in inshore waters rather than when it has arrived on the beach would have dual benefits.
\end{abstract}

Keywords: seagrass; Thallasia testudinum; brown tide; tourism; fisheries; tour operators; management; sargassum brown tide; beach

\section{Introduction}

Note: the term sargassum is used in this report as the common name for the Sargassum species found in the beach drift on the Turks and Caicos Islands, predominantly S. fluitans III and S. natans I and VIII.

In recent years, the Caribbean has experienced sudden inundations of seaweed masses on coastlines and beaches, predominantly of the holopelagic Sargassum fluitans III, Sargassum natans I and Sargassum natans VIII [1,2]. Thought to originate from the Sargasso Sea, this is now acknowledged to be from the North Equatorial Recirculation Region (NERR), located off the coast of Brazil and Northwest Africa, drifting into the eastern Caribbean on currents [3-8].

The floating sargassum rafts provide a rich habitat for many species such as sea turtle hatchlings (Chelonioidea spp.), seahorses (Hippocampus spp.), flying fish (Exocoetidae spp.), more than 145 invertebrate species and at least 100 other species of fish reported to use them for forage, refuge, and breeding [9-11]. There is little peer-reviewed evidence on what species remained when the rafts washed on to coastal shores, although there are anecdotal reports of dead fish producing an odor, and of birds feeding amongst the rotting seaweed. Researchers working in the Mexican Caribbean took samples at 2, 5 and $500 \mathrm{~m}$ from the shore and found high diversity and number of individuals in rafts at sea but lower abundance near the shore. This led to the suggestion that harvesting sargassum from within the reef lagoon might be less damaging than taking it from the sea, although this was caveated by the recommendation for more research to inform management decisions [12]. 
There are more than 350 species of seaweed in the genus Sargassum, and these regularly wash onto beaches in small quantities. It is only since 2011 than massive inundations have occurred, damaging local economies and the environment across the Caribbean, Gulf of Mexico, and West Africa [1]. This led to the United Nations producing 'The Sargassum White Paper', referring to "golden tides" and advising monitoring to enable understanding of the abundance and distribution of sargassum landings [13]. This phenomenon has attracted considerable attention as a biomass resource, with commercial potential for products ranging from biochemicals, livestock feed, food, fertilizer, and fuel. However, as pointed out by Milledge and Harvey [14], lack of knowledge of the composition and level of pollutants, combined with the unpredictability of the resource, presents considerable challenges. The warning of potential toxicity has been reiterated in the recent Sargassum Uses Guide [15].

This research, part of a larger project which aimed to address these knowledge gaps, was conducted in the Turks and Caicos Islands, a British Overseas Territory comprising approximately 40 inhabited and uninhabited low limestone islands and golden sandy beaches, in the Atlantic Ocean, southeast of the Bahamas (Figure 1).

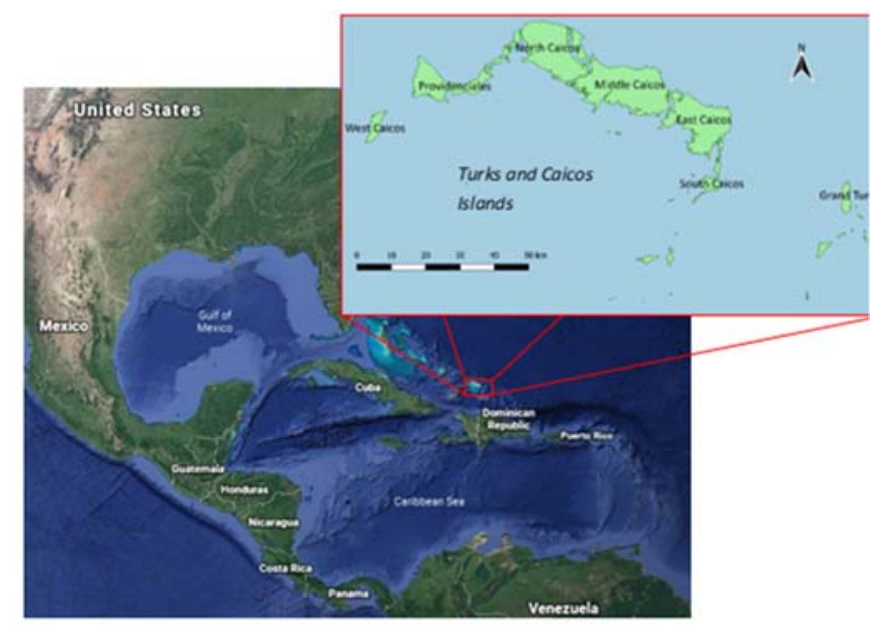

Figure 1. Location of the Turks and Caicos Islands.

The objective was to determine firstly what impact the sargassum was having on tourism-related businesses and secondly whether it was affecting the seagrass meadows known to be important for the economically important fisheries.

The business basis of TCI trade changed with the collapse of solar salt production and the rise of tourism in the mid-1960s, with Caribbean Islands seen as exclusive, upmarket, destinations [16]. Providenciales rose in importance, with tourism described as the engine for economic growth [17] and as 'an economic revolution' [18]. This trend has continued, with a reported $17.5 \%$ increase in tourist arrivals in 2016, estimated at over 455,000 visitors to the archipelago, with a consequent dramatic increase in development, particularly of luxury villas and coastline beach resorts. There is a seasonal pattern, with higher numbers of visitors in winter and early spring. Brief visits, typically measured in hours rather than days, are made by cruise ships calling in to Grand Turk, the only terminal in the islands. The number of ships has increased along with their passenger capacity. Providenciales is the main island, with most resorts, and includes the most famous beach, Grace Bay. It is the gateway for tourists arriving by air, although South Caicos and Grand Turk also have small airports providing inter-island flights, with Grand Turk, to the east, having a cruise ship terminal. The key attraction is the natural environment, particularly the pale sandy beaches and turquoise blue, crystal-clear, water, and this has given rise to the phrase 'beautiful by nature' used in much promotional material. It is abundantly clear that the tourism industry, based on a combination of the pristine beaches and marine wildlife, is vital to the economy of the Turks and Caicos Islands. 
Tourism, prior to the COVID-19 pandemic, made the greatest contribution to the Gross Domestic Product, [19], followed by the offshore banking sector and fisheries, notably Queen conch (Strombus gigas) and spiny lobster (Panulirus argus), which are consumed locally and exported, mostly to the United States [20], with fishing the main economic activity on South Caicos [21]. The same fisher fleet targets both species [22,23]. Historically, Queen conch (Strombus gigas) was the principal food source, with the indigenous Lucayans and Arawak Indians using the TCI as temporary fishing platforms. The conch fishery increased after the collapse of the salt industry [24]. The lobster fishery developed after the introduction of snorkeling and freezing technology in the 1950s and 1960s with export markets in Florida and the US driving demand, with TCI-sourced conch attracting a premium [22].

The Caicos Bank, on the leeward side of the Turks and Caicos Islands, is shallow and sandy with vast seagrass beds consisting of Syringodium filiforme, Halodule wrightii and Thalassia testudinum, the latter being dominant [22]. These sustain the conch, lobster, and fish stocks of the TCI, providing habitat for 56 fish species, representing 22 families, at various points of their life cycle, including 8 of the 10 most abundant species landed by commercial finfish fishers [25]. A study conducted on South Caicos found that the habitat most populated by juvenile lobsters was in East Bay and dominated by the seagrass Thalassia testudinum with approximately 10-20\% cover of the red algae Neogoniolithon [26]. The seagrass beds are also foraging ground for the protected hawksbill (Eretmochelys imbricata) and green sea turtles (Chelonia mydas), which have been harvested in TCI since at least AD 700 [27] although this is now permitted only for domestic consumption [28].

The tourism sector benefits from seagrass beds as they contribute to the crystalclear turquoise waters that lure visitors to the islands. Restaurants often serve seagrassassociated species, such as conch, lobster, Nassau grouper or yellowtail snapper and snorkel and kayak tours visit seagrass meadows so tourists can encounter green sea turtles [29]. However, the tourism industry adversely affects seagrass beds through dredging for ports, marinas and shipping channels, chemical run-off from hotels, use of motorboats and clearance of inshore seagrass to provide guests with a sandy substrate [25].

This study investigated the effects of sargassum on tourism-related businesses and seagrass beds, which are known to support the principal economic sectors of the Turks and Caicos Islands. The first aim was to determine how strongly tourism-related businesses were affected by sargassum inundations and if the impacts varied between islands and between different business types. The second aim was to measure the sargassum accumulations on beaches on South Caicos and Middle Creek Cay and monitor the adjacent seagrass beds to determine if seagrass cover was lost and what type of substrate replaced the lost seagrass. This paper describes the results of the first stage of a larger investigation to address some of the gaps in information necessary to identify and evaluate potential sustainable solutions to the Sargassum inundation, supported by DEFRA Darwin Plus grant number DPR7P $\backslash 100059$.

\section{Method}

This section will first describe the method used to determine the views of local stakeholders and tourism-related businesses regarding the impact of sargassum and secondly the investigation into the inshore sea grass meadows.

\subsection{Stakeholder/Tourist Business Interviews}

Research into the views of local stakeholders, particularly businesses associated with tourism, was carried out during a visit to TCI in June 2019. It comprised face-to-face interviews and focus groups and was conducted on Providenciales, South Caicos and Grand Turk, the three islands with most tourist activity. This combined approach was selected as personal interaction is generally a more effective method of engagement than paper survey [30] and, as time was limited, bringing people together in focus groups effectively increased the number of businesses and stakeholders reached with the additional advantage 
of providing deeper and richer content through interactions and group dynamics which can be particularly informative when there are differing perspectives [31,32]. A framework, serving as the schedule for both the focus groups and semi-structured interviews, was devised in consultation with local partners from both the Department for the Environment and Coastal Resources (DECR) and the School for Field Studies (SFS), based on South Caicos, to ensure questions were relevant and locally appropriate. The questions, with the rationale for each one, are given in Table 1.

Table 1. The interview schedule and rationale for the questions.

\begin{tabular}{|c|c|}
\hline Questions & Rationale \\
\hline Q1. Has sargassum had an impact on your business? & The fundamental rationale for this research. \\
\hline Q2. If yes has this been Low, Moderate or High? & To estimate the scale of impact on business \\
\hline $\begin{array}{l}\text { Q3. Comments on this, e.g., when this happened, amounts of } \\
\text { sargassum, customer comments }\end{array}$ & Supplemental evidence on nature of impact. \\
\hline Q4. When did you first notice sargassum? & $\begin{array}{l}\text { To identify when sargassum began arriving in TCI and to try to } \\
\text { determine if there have been seasonal patterns }\end{array}$ \\
\hline Q5. Are you taking any action such as removing sargassum? & $\begin{array}{l}\text { To establish if businesses affected are removing sargassum } \\
\text { from beaches. }\end{array}$ \\
\hline Q6. If you are removing sargassum how is this done? & $\begin{array}{l}\text { To identify methods and management techniques currently } \\
\text { utilized in TCI. }\end{array}$ \\
\hline Q7. How often? & $\begin{array}{l}\text { To quantify regularity of clean-up and contribute to } \\
\text { understanding level of impact and seasonality. }\end{array}$ \\
\hline Q8. Do you keep a record? & $\begin{array}{l}\text { Any records could contribute to quantifying impact and } \\
\text { quantity arriving and when this is happening. }\end{array}$ \\
\hline $\begin{array}{l}\text { Q9. Request for any further information on sightings of } \\
\text { sargassum on beaches }\end{array}$ & $\begin{array}{l}\text { To collect data, build records of frequency and size of } \\
\text { inundations and continue engagement on this issue. }\end{array}$ \\
\hline
\end{tabular}

The focus groups were advertised by DECR on their website and on posters displayed in places frequented by tourism-related business operatives. The meetings were hosted by DECR in their offices on Providenciales and South Caicos, by the National Museum on Grand Turk, and the Sustainable Tourism Association, again on Providenciales.

All meetings began with the two MSc students from the University of Greenwich, who were acting as research assistants, presenting desk study research they had done into sargassum prior to visiting TCI. This included an overview of the sargassum issue across the Caribbean region and information on the ecology and species associated with the floating rafts to provide a context for this research.

The semi-structured interviews were conducted face to face with individual businesses identified from advertisements and publicity material aimed at tourists. These were visited and the interviewer recorded responses on a pre-prepared form, based on the questions in Table 1, with any additional information and the business type noted. Where possible, potential respondents were phoned in advance and an appointment made; those operating from shops or beach-side locations were approached directly but given the option for the interviewer to return at a more convenient time.

\subsection{Data Analysis}

Focus group discussions were transcribed, and the content analyzed thematically. Differences in the views of participants on different Islands were identified, as well as themes emerging for TCI as a whole.

Interview responses were input into an excel spreadsheet and countif(s) functions used to enable extraction of specific criteria and used if there was more than one condition being analyzed. Some analysis was split by island and/or business type to enable interpretation using tables and graphs. 


\subsection{Sargassum and Seagrass Surveys}

Ten beach sites were surveyed for seagrass and sargassum coverage, East Bay Beach, Coast Guard, Shark Bay Beach, East of Shark Bayt, Long Bay Beach North, Long Bay Beach South, and Highland House, all on the windward side of South Caicos Island, and the beaches at the End, Middle, and Tip of Middle Creek Cay, just north of the South Caicos peninsula (Figure 2). All these sites consisted of sandy beaches, with sand plain, algal plain, patch reefs, rock, or seagrass beds in the shallow water, typically less than $3 \mathrm{~m}$ deep.

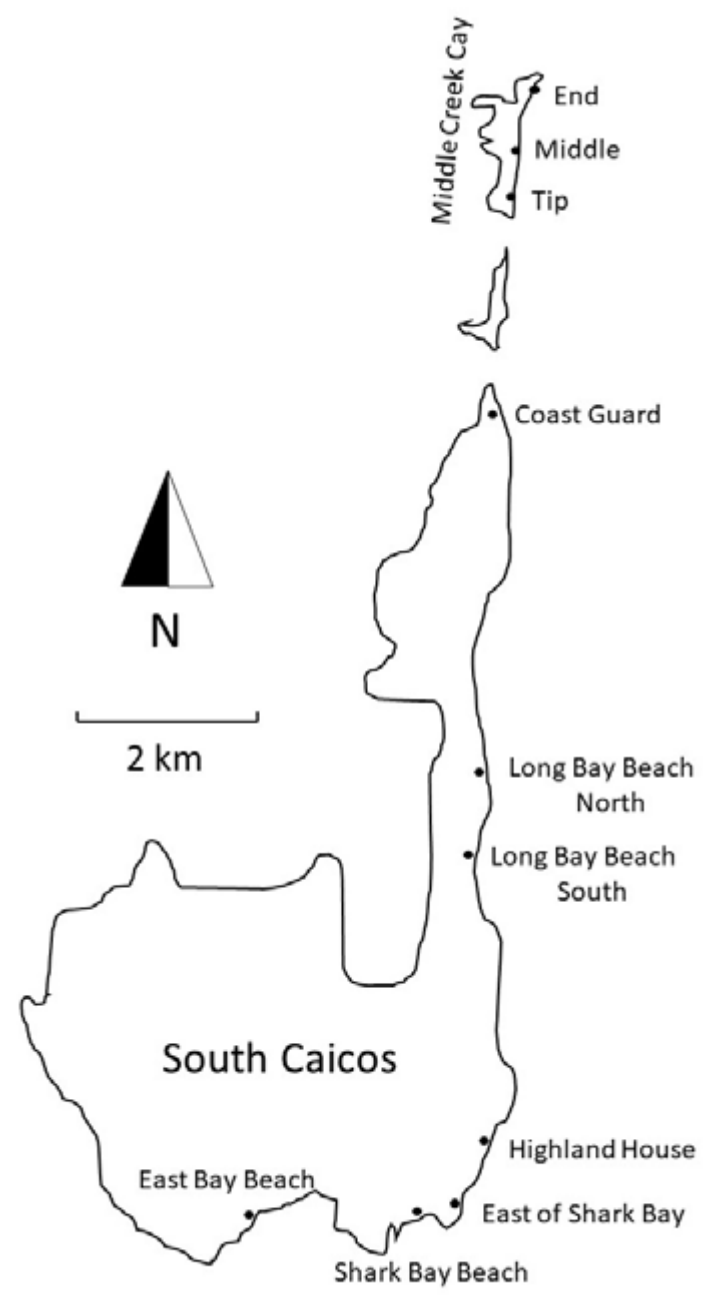

Figure 2. Map showing the 10 beaches and adjacent seagrass beds surveyed on South Caicos and Middle Creek Cay.

In November and December 2018, Middle Creek Cay End and Middle as well as the two Long Bay Beach sites were monitored and large areas covered in dense stumps of the seagrass species T. testudinum were found, indicating recent loss of seagrass beds. These sites as well as Middle Creek Cay Tip were monitored again in February and March of 2019. In April 2019, a large effort was put in place to monitor all accessible eastward facing beaches on South Caicos and Middle Creek Cay (Table 2). This effort was replicated in November and December; however, the two beaches that are regularly cleaned were not included in the surveys at that time. 
Table 2. List of survey sites for beach and in-water surveys listed from north to south including the dates they were surveyed.

\begin{tabular}{ccccc}
\hline Site & Nov/Dec 2018 & Feb/March 2019 & April 2019 & Sept/Nov/Dec 2019 \\
\hline Middle Creek Cay End & 29 November 2018 & 13 February 2019 & 8 April 2019 & 2 December 2019 \\
Middle Creek Cay Middle & 29 November 2018 & 13 February 2019 & 8 April 2019 & 2 December 2019 \\
Middle Creek Cay Tip & & 24 February 2019 & 8 April 2019 & 2 December 2019 \\
Coast Guard & & & 18 April 2019 & 20 November 2019 \\
Long Bay Beach North & 8 December 2018 & 2 March 2019 & 4 April 2019 & 19 September 2019 \\
Long Bay Beach South & 8 December 2018 & 2 March 2019 & 4 April 2019 & 11 April 2019 November 2019 \\
Highland House & & & 11 April 2019 & 14 November 2019 \\
East of Shark Bay & & & 11 April 2019 & 7 November 2019 \\
Shark Bay Beach & & & 17 April 2019 \\
East Bay Beach & & & & \\
\hline
\end{tabular}

If sargassum was present on the beach, a transect was walked, placing the weighted end of the line at the start of the pile (or row) of beached material closest to the water's edge, and then pulling the line perpendicular to the water until the end of the pile. The depth of the sargassum deposit was determined by digging through it until sand was reached and the transect line placed inside it. At the $0.5 \mathrm{~m}$ mark and at each $1 \mathrm{~m}$ mark on the transect line, the depth was measured in $\mathrm{cm}$. This enabled the cross-sectional area to be calculated using the following formulas:

Cross sectional

$$
\begin{aligned}
=\frac{h_{0.5} \times 50 \mathrm{~cm}}{2}+ & h_{0.5} \times 50 \mathrm{~cm}+\frac{\left(h_{1}-h_{0.5}\right) \times 50 \mathrm{~cm}}{2}+\frac{\left(h_{n}-h_{n-1}\right) \times 100 \mathrm{~cm}}{2} \\
& +\sum_{k}^{n-1}\left(h_{k} \times 100 \mathrm{~cm}+\frac{\left(h_{k+1}-h_{k}\right) \times 100 \mathrm{~cm}}{2}\right)
\end{aligned}
$$

$h_{\mathrm{x}}=$ measured height of Sargassum at the $1 \mathrm{~m}$ mark $\mathrm{x}$, and

$n=$ last $1 \mathrm{~m}$ mark that had Sargassum below it.

Pictures of the beaches were taken using a Galaxy S8 Active smart phone, a Sealife DC2000 underwater camera, and a GoPro.

\subsection{Seagrass Cover}

The distribution of seagrass habitat was mapped by snorkeling three separate $100 \mathrm{~m}$ long transects perpendicular to the shore and $5 \mathrm{~m}$ apart from each other at each of the 10 sites. The surveyor swam along these lines, noting at each $1 \mathrm{~m}$ the dominant substrate: sand, living and dead seagrass. Results were recorded graphically, and photographs were taken at the sites of the Sargassum on the beach.

\section{Results}

This will follow the same order as the method, the focus groups and interviews, followed by the beach and in-water surveys.

\subsection{Focus Groups}

The numbers attending and the composition of the groups was varied (see Table 3), with males predominating. It was not possible to record the occupation or particular interest of the attendees as some were keen to remain anonymous; being hosted by DECR and the presence of officers may have been an issue. 
Table 3. Focus Group composition.

\begin{tabular}{ccccc}
\hline Location & Host & Meeting Time & Males & Females \\
\hline Providenciales & DECR offices & Evening & 9 & 1 \\
\hline Grand Turk & DECR/National Museum & Afternoon & 11 & 4 \\
\hline South Caicos & DECR offices & Evening & 3 & 3 \\
\hline Providenciales & The Sustainable Tourism Association & Afternoon & 26 & 6 \\
\hline
\end{tabular}

The discussions were recorded in note form, and the discussion points organized into themes for analysis.

Positive impacts were raised in 12 separate comments (Table 4) and negative ones in 18 (Table 5). The largest number of comments (15) and most detailed discussion occurred during the focus group on Grand Turk.

Table 4. The Positive Impact of Sargassum (PLS = Providenciales; GDT = Grand Turk; XSC = South Caicos; STA = Sustainable Tourism Association).

\begin{tabular}{ccccc}
\hline PLS & GDT & XSC & STA & Positive Comments \\
\hline 1 & 1 & 2 & $\begin{array}{c}\text { Sports fishers benefit from more fish (particularly } \\
\text { Mahi-mahi) using the rafts }\end{array}$ \\
\hline 1 & & 1 & Line fishing catches \\
\hline 1 & 1 & 1 & Many birds are catching fish in sargassum \\
\hline & & 1 & 1 & Sargassum is good-as long as it stays out at sea \\
\hline
\end{tabular}

Table 5. Negative Impact of Sargassum (PLS = Providenciales; GDT = Grand Turk; XSC = South Caicos; STA = Sustainable Tourism Association).

\begin{tabular}{|c|c|c|c|c|}
\hline PLS & GDT & XSC & STA & Negative Comments \\
\hline & 1 & & & Sargassum affecting kayaking for cruise passengers in north creek \\
\hline & 1 & & 1 & $\begin{array}{c}\text { Problem for horse rides as horses sink into it, and react badly to floating sargassum } \\
\text { round their legs }\end{array}$ \\
\hline \multirow[t]{11}{*}{1} & & & & Consensus sargassum has become an issue over the last $2-3$ years \\
\hline & 2 & & & Obstructs light that promotes algae growth on sea grass beds conch feed on; corals \\
\hline & 2 & & & $\begin{array}{l}\text { Effect on mangroves depends on species (red, black, white); spiny lobster needs } \\
\text { mangroves as breeding site }\end{array}$ \\
\hline & 2 & & & Effect on human health of decomposing sargassum; unpleasant smell \\
\hline & 1 & & & Hydroids on sargassum irritate human skin \\
\hline & 1 & & & Sargassum means sharks cannot be seen on the east side \\
\hline & 1 & & & Dead fish in the sargassum causes a fly problem \\
\hline & & 1 & & $\begin{array}{l}\text { Fish yields have reduced significantly (from } 700 \text { to } 800 \mathrm{lbs} \text { of conch a day to } 80 \text { to } \\
\qquad 100 \mathrm{lbs} \text { )—is this related to sargassum? }\end{array}$ \\
\hline & & 1 & 1 & $\begin{array}{l}\text { Guests checking out of affected hotels, moving to others or cancelled their } \\
\text { bookings; poor reviews on Trip Advisor }\end{array}$ \\
\hline & & 1 & & Concern was raised about turtle nesting sites and damage to seagrass beds \\
\hline & & & 1 & What is the real economic impact-real estate? \\
\hline 1 & 11 & 3 & 3 & 18 \\
\hline
\end{tabular}


There was discussion about whether sargassum landings were a new phenomenon or if these had just been more severe recently with the issue of nomenclature being raised (Table 6).

Table 6. Occurrence and location of inundations $(\mathrm{PLS}=$ Providenciales; GDT $=$ Grand Turk; $\mathrm{XSC}=$ South Caicos; STA = Sustainable Tourism Association).

\begin{tabular}{|c|c|c|c|c|}
\hline PLS & GDT & XSC & STA & Comments \\
\hline 1 & & & & Sargassum is brought in by the north wind \\
\hline 1 & & & & Tourism is on the west of Grand Turk, Sargassum on the easterly coast \\
\hline \multirow[t]{6}{*}{1} & & & & Caribbean wide problem \\
\hline & 1 & & & Older ridge residents reported it has been as bad in the past (but when?) \\
\hline & 1 & & & Big rafts form in calm weather, wind breaks up so it becomes a nuisance \\
\hline & 1 & & & Enough in Pigs Ear Bay last week to fill a shipping container \\
\hline & 1 & & & $8 \mathrm{ft}$ depth of deposited sargassum recorded on the east side of the island \\
\hline & & 2 & & $\begin{array}{c}\text { How recent is the problem? Was there sargassum } 30 \text { years ago in East Bay or was it } \\
\text { seaweed? Or sea grass? }\end{array}$ \\
\hline \multirow[t]{2}{*}{1} & & & & $\begin{array}{l}\text { Grace Bay is on the side of Provo least affected, Sargassum only comes in when the } \\
\text { SE-NW Trades move to the north }\end{array}$ \\
\hline & & & 2 & First a problem in 2011, then in 2012/13/14. Worst in March/April \\
\hline 2 & & & & It has been an issue in the last $2-3$ years; longer on GT \\
\hline 1 & & & & Dive instructors have seen bigger blooms in the last $2-3$ years out to sea \\
\hline \multirow[t]{2}{*}{1} & & & & Always been present, now more, and more troublesome, last four or five years \\
\hline & & & 1 & In 2018 and 2019, it has come in May and lasted into the summer months \\
\hline 8 & 4 & 2 & 3 & 17 \\
\hline
\end{tabular}

Questions 5, 6 and 7 focused on whether sargassum was being removed and what method was used. The results were varied, with least removal on Grand Turk (Table 7).

Table 7. Removal and disposal of sargassum (PLS = Providenciales; GDT = Grand Turk; XSC = South Caicos; STA = Sustainable Tourism Association).

\begin{tabular}{|c|c|c|c|c|}
\hline PLS & GDT & XSC & STA & Comments \\
\hline 1 & & & & Raking it from water onto shore or at the water's edge is the most common method. \\
\hline 1 & & & & $\begin{array}{l}\text { Raking into the sea to clean it (removes sand) but required } 4-5 \text { members of staff daily for a } \\
\text { four-months then to be bagged up, put into a skip and taken off site to dump. }\end{array}$ \\
\hline 1 & & & & This was successful but labour intensive. \\
\hline 1 & & & & consensus visitors were pleased to see attempts made to remove sargassum. \\
\hline 1 & & & & There is currently no integration of management between hoteliers. \\
\hline 1 & & & & $\begin{array}{l}\text { unsuccessfully, to use a boom to hold seaweed but this created a vortex and sucked it in to } \\
\text { the shore side. }\end{array}$ \\
\hline & 1 & & & East Bay removed sea grass under license from the DECR. \\
\hline & & 1 & & East Bay have 3 men raking every day; cheaper than fuel (very expensive). \\
\hline & & 1 & & have not used the Barber Surf Raker for several months. \\
\hline & & 1 & & Interest in a hay lifting type of machines-lift the seaweed leaving the sand behind. \\
\hline & & 1 & & Overall, the problem is manageable-at the moment. \\
\hline & & 1 & & $\begin{array}{l}\text { Hand raking and burying the sargassum is good for the beach as it stabilises it but if there } \\
\text { is too much then it has to be removed and taken off site. }\end{array}$ \\
\hline
\end{tabular}


Table 7. Cont.

\begin{tabular}{|c|c|c|c|c|}
\hline PLS & GDT & XSC & STA & Comments \\
\hline & & & 1 & $\begin{array}{l}\text { Guidance discussed-inconsistent and varied between burying at the shoreline, past the } \\
\text { shoreline or off the beach or to bag and take it to the dump. }\end{array}$ \\
\hline & & & 1 & Day labourers paid minimum wage (\$6.25); 50-200 bags removed a day. \\
\hline & & & 1 & Interest in 'sweepys' between hand raking and the Barber surf rake (used in Florida). \\
\hline & & & 1 & A review of the effectiveness of all available options is needed. \\
\hline 6 & 1 & 5 & 4 & 16 \\
\hline
\end{tabular}

The potential for a commercially viable end use for sargassum was a topic of great interest, with a variety of views expressed (Table 8), although the uncertainty around the composition, salinity, and potential toxicity clearly considered barriers to progress without further research.

Table 8. Potential end uses (PLS = Providenciales; GDT = Grand Turk; XSC = South Caicos; STA = Sustainable Tourism Association).

\begin{tabular}{|c|c|c|c|c|}
\hline PLS & GDT & XSC & STA & Comments \\
\hline \multirow[t]{6}{*}{1} & & & & Fertiliser potential was discussed. \\
\hline & 1 & & & Very high salt levels were mentioned. \\
\hline & 1 & & & Animal feed? One horse observed eating it by Lighthouse. \\
\hline & 1 & & & What if it does contain heavy metals? \\
\hline & \multirow[t]{2}{*}{1} & & & Project to make fuel in China failed due to supply of raw material. \\
\hline & & & 1 & Could it be composted? This is done in Barbados, but needs water for washing. \\
\hline 1 & 4 & & 1 & 6 \\
\hline
\end{tabular}

Other themes that emerged during the focus groups are recorded in Table 9.

Table 9. Topics raised by focus group participants $(p=$ Providenciales; GT = Grand Turk; SC = South Caicos; STA $=$ Sustainable Tourism Association.

\begin{tabular}{|c|c|c|c|c|}
\hline PLS & GDT & XSC & STA & Comments \\
\hline 1 & & & & $\begin{array}{l}\text { Surprise from some who had not realized sargassum was floating-they had thought it } \\
\text { was attached to the seabed and stirred up by winds and storms. }\end{array}$ \\
\hline \multirow[t]{10}{*}{1} & & & & Why are wider links not being made? \\
\hline & 1 & & & $\begin{array}{l}\text { Concern that many do not know what it is and think it is } \\
\text { sewage-education/interpretation is needed. }\end{array}$ \\
\hline & 1 & & & Changes in beach shape was discussed; it changes regularly with storms. \\
\hline & 1 & & & $\begin{array}{l}\text { after hurricanes it takes a few years for marine to settle-is sargassum just a symptom of } \\
\text { this? Nutrients coming up from the bottom "the ocean is just cleaning itself". }\end{array}$ \\
\hline & 1 & & & $\begin{array}{l}\text { Sargassum is locally referred to as 'weed' or 'grass' - care is needed in interpreting } \\
\text { comments as there is potential confusion with seagrass. }\end{array}$ \\
\hline & & 1 & & Three types, floating rafts, small floating masses and washed up on the beach. \\
\hline & & & 1 & of erosion-in Turtle Cove there has been 2 feet lost in the last few weeks. \\
\hline & & & 1 & The whole of TCI is based on the value of real estate. \\
\hline & & & 1 & visitor comments be asked for about the 'beautiful by nature' beaches? \\
\hline & & & 1 & $\begin{array}{l}\text { want to have a policy on sargassum removal. They have a 'TCI cares' initiative promoting } \\
\text { wildlife, banning plastics and are keen to develop more initiatives. }\end{array}$ \\
\hline 2 & 4 & 1 & 4 & 12 \\
\hline
\end{tabular}




\subsection{Face-to-Face Interviews}

The questionnaire-based interviews began in Providenciales, the island with greatest concentration of tourism businesses, with 60 completed forms collected, with further interviews completed on South Caicos (20) and Grand Turk (20). Seventy-one respondents were male, 29 females. In response to Question 1, which asked Has sargassum had an impact on your business? $58 \%$ responded in the affirmative, shown by island in Table 10; $42 \%$ that it had not.

Table 10. Number (and \%) reporting impact by business category.

\begin{tabular}{|c|c|c|c|c|c|c|c|c|c|c|c|c|}
\hline \multirow[t]{2}{*}{ Business Category } & \multicolumn{4}{|c|}{ Total Responses } & \multicolumn{4}{|c|}{$\begin{array}{l}\text { Number Reporting Impact } \\
\text { (Responding 'Yes' to Q1) }\end{array}$} & \multicolumn{4}{|c|}{$\begin{array}{c}\text { Percentages Impacted } \\
\text { Per Business }\end{array}$} \\
\hline & All & PLS & GDT & XCS & All & PLS & GDT & XCS & All & PLS & GDT & XCS \\
\hline Restaurant/bar & 11 & 8 & 1 & 2 & 6 & 5 & 0 & 1 & 55 & 63 & 0 & 50 \\
\hline Fishing & 7 & 1 & 1 & 5 & 6 & 1 & 1 & 4 & 86 & 100 & 100 & 80 \\
\hline Sports fishing & 6 & 4 & 1 & 1 & 6 & 4 & 1 & 1 & 100 & 100 & 100 & 100 \\
\hline Resort & 9 & 4 & 0 & 5 & 7 & 3 & 0 & 4 & 78 & 75 & $\mathrm{~N} / \mathrm{A}$ & 80 \\
\hline Accommodation & 4 & 3 & 1 & 0 & 3 & 3 & 0 & 0 & 75 & 100 & 0 & $\mathrm{~N} / \mathrm{A}$ \\
\hline Real estate/developer & 4 & 4 & 0 & 0 & 3 & 3 & 0 & 0 & 75 & 75 & $\mathrm{~N} / \mathrm{A}$ & $\mathrm{N} / \mathrm{A}$ \\
\hline Wildlife charity & 1 & 1 & 0 & 0 & 0 & 0 & 0 & 0 & 0 & 0 & $\mathrm{~N} / \mathrm{A}$ & $\mathrm{N} / \mathrm{A}$ \\
\hline Snorkeling/Diving & 11 & 7 & 3 & 1 & 5 & 2 & 3 & 0 & 45 & 29 & 100 & 0 \\
\hline Surface water sports & 9 & 7 & 2 & 0 & 6 & 4 & 2 & 0 & 67 & 57 & 100 & $\mathrm{~N} / \mathrm{A}$ \\
\hline Shore leisure & 5 & 2 & 3 & 0 & 3 & 1 & 2 & 0 & 60 & 50 & 67 & $\mathrm{~N} / \mathrm{A}$ \\
\hline Market trader & 12 & 8 & 2 & 2 & 2 & 2 & 0 & 0 & 17 & 25 & 0 & 0 \\
\hline Travel/boat trips & 12 & 6 & 3 & 3 & 7 & 2 & 2 & 3 & 58 & 33 & 67 & 100 \\
\hline Farmer & 1 & 1 & 0 & 0 & 1 & 1 & 0 & 0 & 100 & 100 & $\mathrm{~N} / \mathrm{A}$ & $\mathrm{N} / \mathrm{A}$ \\
\hline $\begin{array}{l}\text { Independent tourism } \\
\text { consultant }\end{array}$ & 2 & 2 & 0 & 0 & 1 & 1 & 0 & 0 & 50 & 50 & $\mathrm{~N} / \mathrm{A}$ & $\mathrm{N} / \mathrm{A}$ \\
\hline Tourist board & 2 & 1 & 1 & 0 & 2 & 1 & 1 & 0 & 100 & 100 & 100 & $\mathrm{~N} / \mathrm{A}$ \\
\hline Entrepreneur & 1 & 1 & 0 & 0 & 0 & 0 & 0 & 0 & 0 & 0 & $\mathrm{~N} / \mathrm{A}$ & $\mathrm{N} / \mathrm{A}$ \\
\hline Utilities/services & 1 & 0 & 0 & 1 & 0 & 0 & 0 & 0 & 0 & $\mathrm{~N} / \mathrm{A}$ & $\mathrm{N} / \mathrm{A}$ & 0 \\
\hline Government dep. & 1 & 0 & 1 & 0 & 0 & 0 & 0 & 0 & 0 & $\mathrm{~N} / \mathrm{A}$ & 0 & $\mathrm{~N} / \mathrm{A}$ \\
\hline Museum & 1 & 0 & 1 & 0 & 0 & 0 & 0 & 0 & 0 & $\mathrm{~N} / \mathrm{A}$ & 0 & $\mathrm{~N} / \mathrm{A}$ \\
\hline Totals & 100 & 60 & 20 & 20 & 58 & 33 & 12 & 13 & 58 & 55 & 60 & 65 \\
\hline
\end{tabular}

Table 11 shows the scale of impact reported.

Table 11. Scale of impact, both negative and positive. ( $p=$ Providenciales; GT = Grand Turk; SC = South Caicos; STA = Sustainable Tourism Association).

\begin{tabular}{ccccc}
\hline Negative Impact & All & PLS & GDT & XCS \\
\hline low & 21 & 12 & 4 & 5 \\
moderate & 17 & 8 & 4 & 5 \\
high & 16 & 10 & 3 & 3 \\
Total & 30 & 11 & 13 \\
Positive Impact & 54 & 0 & 0 & 0 \\
low & 0 & 2 & 0 & 0 \\
moderate & 2 & 0 & 0 & 0 \\
High & 0 & 2 & 0 & 0 \\
Total & 2 & & &
\end{tabular}


Table 11. Cont.

\begin{tabular}{ccccc}
\hline Negative Impact & All & PLS & GDT & \\
\hline Mixed Impact & & & 1 & 0 \\
low & 3 & 2 & 0 & 1 \\
moderate & 1 & 0 & 0 & 0 \\
high & 0 & 0 & 1 & 1 \\
Total & 4 & 2 & & \\
\hline
\end{tabular}

The next question asked when sargassum was first observed, and the results are shown in Figure 3. This shows it has been more significant in recent years and in 2018 particularly.

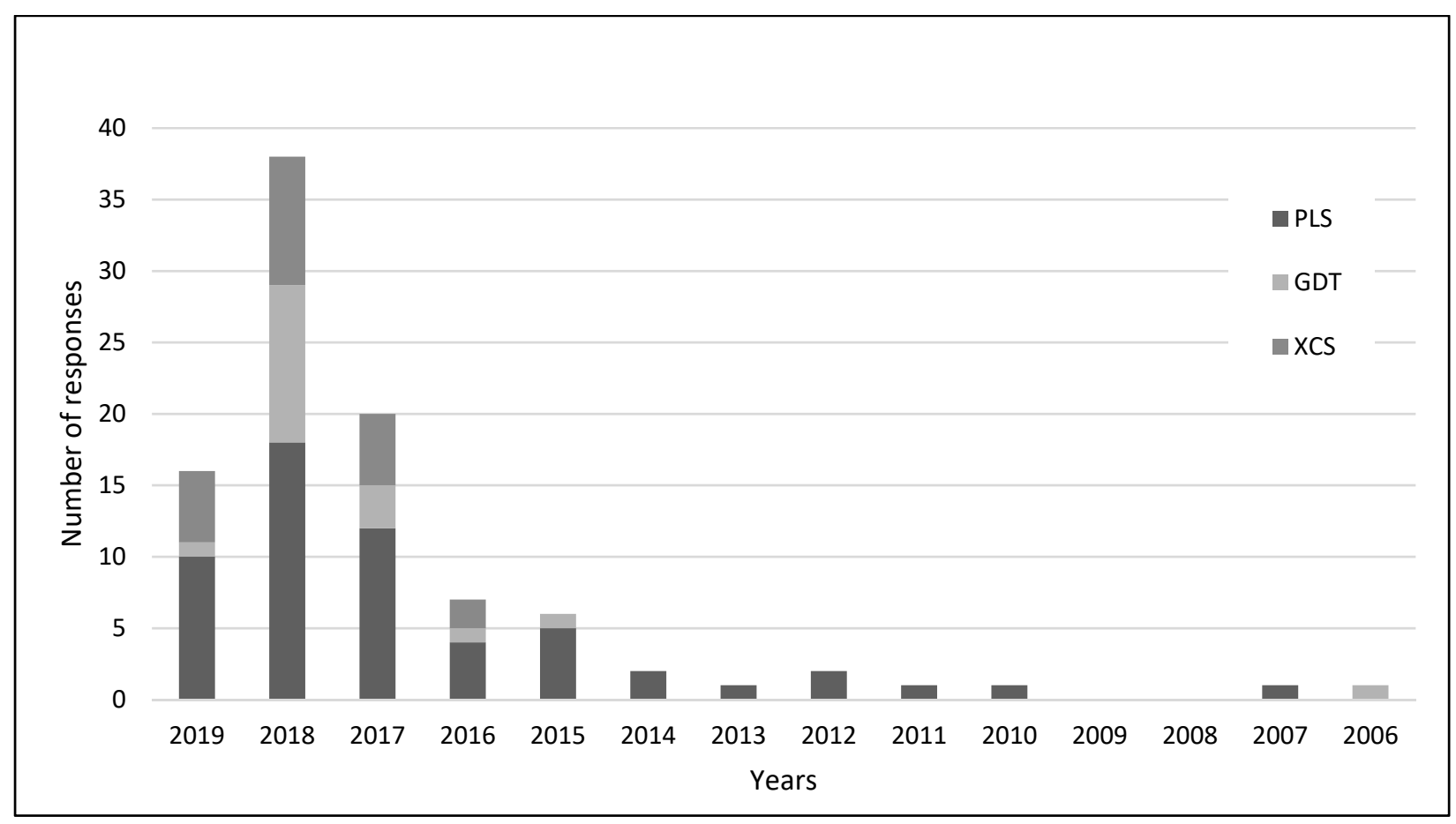

Figure 3. The years sargassum was an issue on TCI (PLS = Providenciales; GDT = Grand Turk; XCS = South Caicos).

This was further investigated by asking about the seasonality of beach inundation and this is shown by month in Figure 4. The results suggest that beach inundation mostly occurs in mid/late summer so it must be remembered that these surveys were all carried out in June 2019, particularly when considering Figure 3.

Despite similar proportions reporting impact, $71 \%$ of accommodation- and foodrelated businesses (restaurants/bars, accommodation, resorts, and real estate) reported action, far more than the $44 \%$ of activity providers (travel/ boat trips, snorkeling/diving, surface water sports, sports fishing, shore leisure). Of the impacted businesses, $82 \%$ took action such as removing Sargassum (Table 12). The most reactive business sector was resorts with all impacted businesses engaged in removal. Two resorts who claimed not to be experiencing any impact also said they were removing sargassum. 


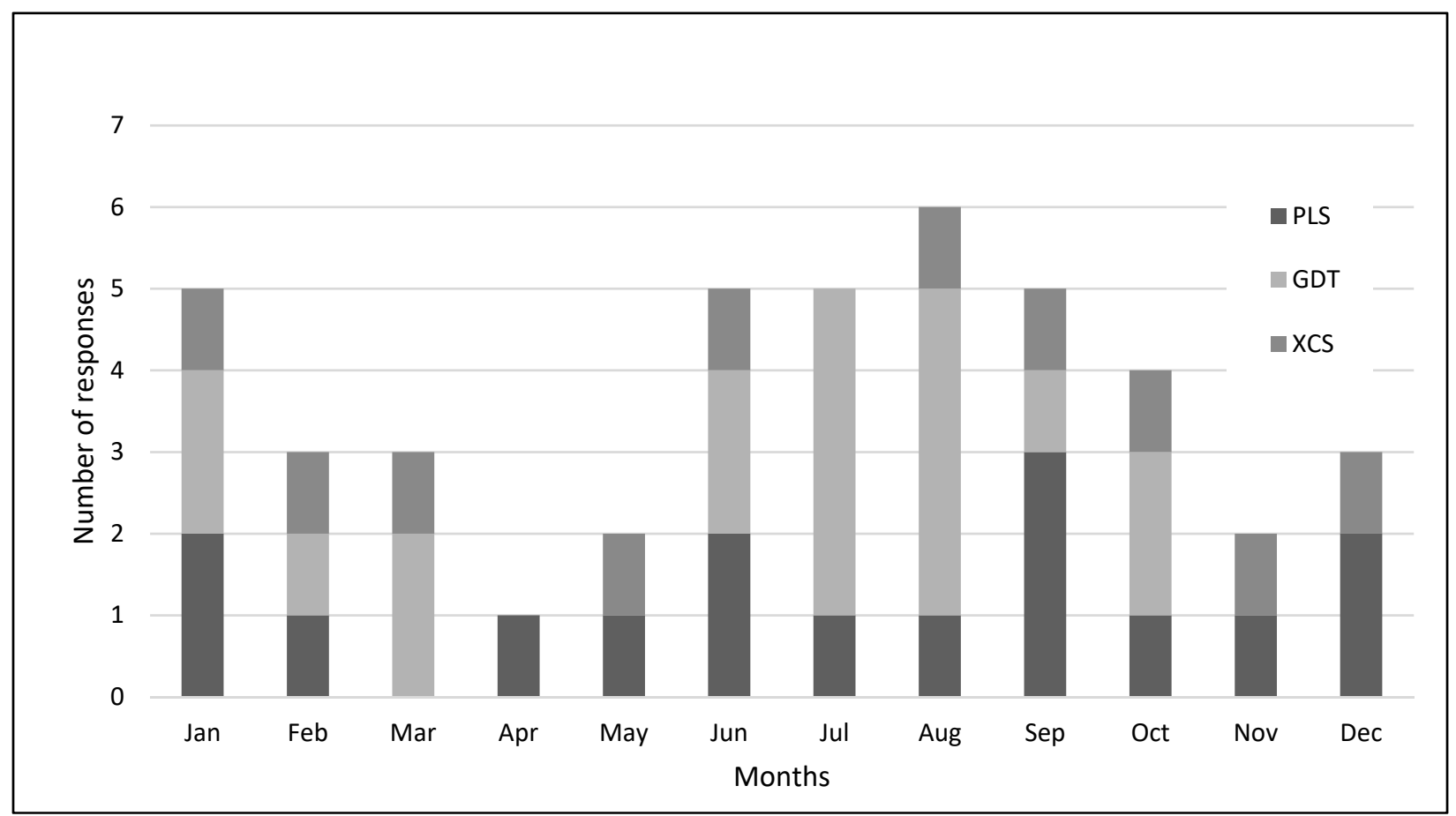

Figure 4. The seasonality of sargassum washing onto beaches; interviewees were asked to indicate all months that they observed sargassum (PLS = Providenciales; GDT = Grand Turk; XCS = South Caicos).

Table 12. Showing many of the businesses surveyed were impacted and how many of those who took action $(\mathrm{PLS}=$ Providenciales; GDT $=$ Grand Turk; $\mathrm{XCS}=$ South Caicos $)$.

\begin{tabular}{|c|c|c|c|c|c|c|c|c|}
\hline & \multicolumn{2}{|c|}{ ALL } & \multicolumn{2}{|c|}{ PLS } & \multicolumn{2}{|c|}{ GDT } & \multicolumn{2}{|c|}{ XCS } \\
\hline & Impact & Action & Impact & Action & Impact & Action & Impact & Action \\
\hline Resort & 7 & 9 & 3 & 4 & 0 & 0 & 4 & 5 \\
\hline Restaurant/bar & 6 & 5 & 5 & 5 & 0 & 0 & 1 & 0 \\
\hline Surface water sports & 6 & 8 & 4 & 6 & 2 & 2 & 0 & 0 \\
\hline Fishing & 6 & 1 & 1 & 1 & 1 & 0 & 4 & 0 \\
\hline Sports fishing & 6 & 5 & 4 & 3 & 1 & 1 & 1 & 1 \\
\hline Snorkeling/Diving & 5 & 2 & 2 & 1 & 3 & 1 & 0 & 0 \\
\hline Shore leisure & 3 & 4 & 1 & 2 & 2 & 2 & 0 & 0 \\
\hline Accommodation & 3 & 4 & 3 & 3 & 0 & 1 & 0 & 0 \\
\hline Real estate/developer & 3 & 2 & 3 & 2 & 0 & 0 & 0 & 0 \\
\hline Market trader & 2 & 1 & 2 & 1 & 0 & 0 & 0 & 0 \\
\hline Tourist board & 2 & 1 & 1 & 0 & 1 & 1 & 0 & 0 \\
\hline $\begin{array}{l}\text { Independent tourism } \\
\text { consultant }\end{array}$ & 1 & 1 & 1 & 1 & 0 & 0 & 0 & 0 \\
\hline Farmer & 1 & 1 & 1 & 1 & 0 & 0 & 0 & 0 \\
\hline Totals & 51 & 44 & 31 & 30 & 10 & 8 & 10 & 6 \\
\hline
\end{tabular}

Raking and shovels was the most used method for sargassum removal used by $58 \%$ of the businesses, while only one business on Providenciales was using a boom (Table 13). On South Caicos the sargassum was most frequently piled on the beach for disposal, while on Providenciales it was often taken to the municipal dump or buried; Grand Turk used all three methods equally. One business on Providenciales was also composting the sargassum. All businesses in Grand Turk would remove Sargassum daily or several times a day, this was also the most common removal frequency for Providenciales and South Caicos, although some businesses removed sargassum less frequently. 
Table 13. Removal Method, frequency, and disposal on the different islands (note some used more than one). $($ PLS $=$ Providenciales; GDT $=$ Grand Turk; XCS $=$ South Caicos $)$.

\begin{tabular}{|c|c|c|c|c|}
\hline Removal Method & All & PLS & GDT & $\mathrm{XCS}$ \\
\hline Raking and shovels & 30 & 23 & 5 & 2 \\
\hline Machines & 11 & 4 & 2 & 5 \\
\hline $\begin{array}{l}\text { Hand cleaning of } \\
\text { equipment }\end{array}$ & 8 & 5 & 2 & 1 \\
\hline $\begin{array}{l}\text { From water using hand } \\
\text { tools }\end{array}$ & 2 & 2 & 0 & 0 \\
\hline Boom & 1 & 1 & 0 & 0 \\
\hline \multicolumn{5}{|l|}{ Disposal method } \\
\hline Pile on beach & 8 & 2 & 1 & 5 \\
\hline Skip/dump & 7 & 4 & 1 & 2 \\
\hline Burying it & 5 & 4 & 1 & 0 \\
\hline Composting & 1 & 1 & 0 & 0 \\
\hline \multicolumn{5}{|l|}{ Frequency of removal } \\
\hline Daily & 23 & 15 & 4 & 4 \\
\hline Weekly & 5 & 4 & 0 & 1 \\
\hline Monthly & 4 & 4 & 0 & 0 \\
\hline When necessary & 3 & 3 & 0 & 0 \\
\hline Other & 7 & 4 & 2 & 1 \\
\hline
\end{tabular}

Responses listed under the 'other' options ranged from twice a day, 2-3 times a day and in three cases all day. Another common response was when it is bad, so action is on an as necessary basis.

Basic content analysis of all the responses revealed the most frequently mentioned impact of sargassum impact related to its removal (22), with some also commenting that this was not permitted. The unpleasant smell was commented on by 15 , with 12 referring to aesthetic appearance. 14 mentioned sargassum affecting equipment, from fishing lines, boat propellers to jet skis. A further 12 specifically referred to the negative impact sargassum had on tourism, although 14 felt it had no impact; 6 expressed the view that it was simply a natural phenomenon and not something to get worried about. A total of 12 raised health and safety issues. Similar views were expressed in the focus group discussions, with the unpleasant smell specifically an issue on Grand Turk.

Q8 The final question asked if a record was kept of the quantities removed. Only 2 replied in the affirmative, with one reporting a specific beach clean that generated 52 refuse sacksful in four hours, from a 100 m of Lower Bight Beach (in April 2019).

\subsection{Sargassum Loads and Interaction with Seagrass Beds}

Dried loose, wet compacted and dry compacted sargassum was found on many of the beaches surveyed on South Caicos and Middle Creek Cay. Only two, East Bay Beach and Long Bay Beach North, are cleared regularly, all other beaches represent natural accumulation of sargassum that can be anywhere between several hours to several months old. The amounts varied between the sites and surveys, with no clear pattern apparent (Figure 5). 

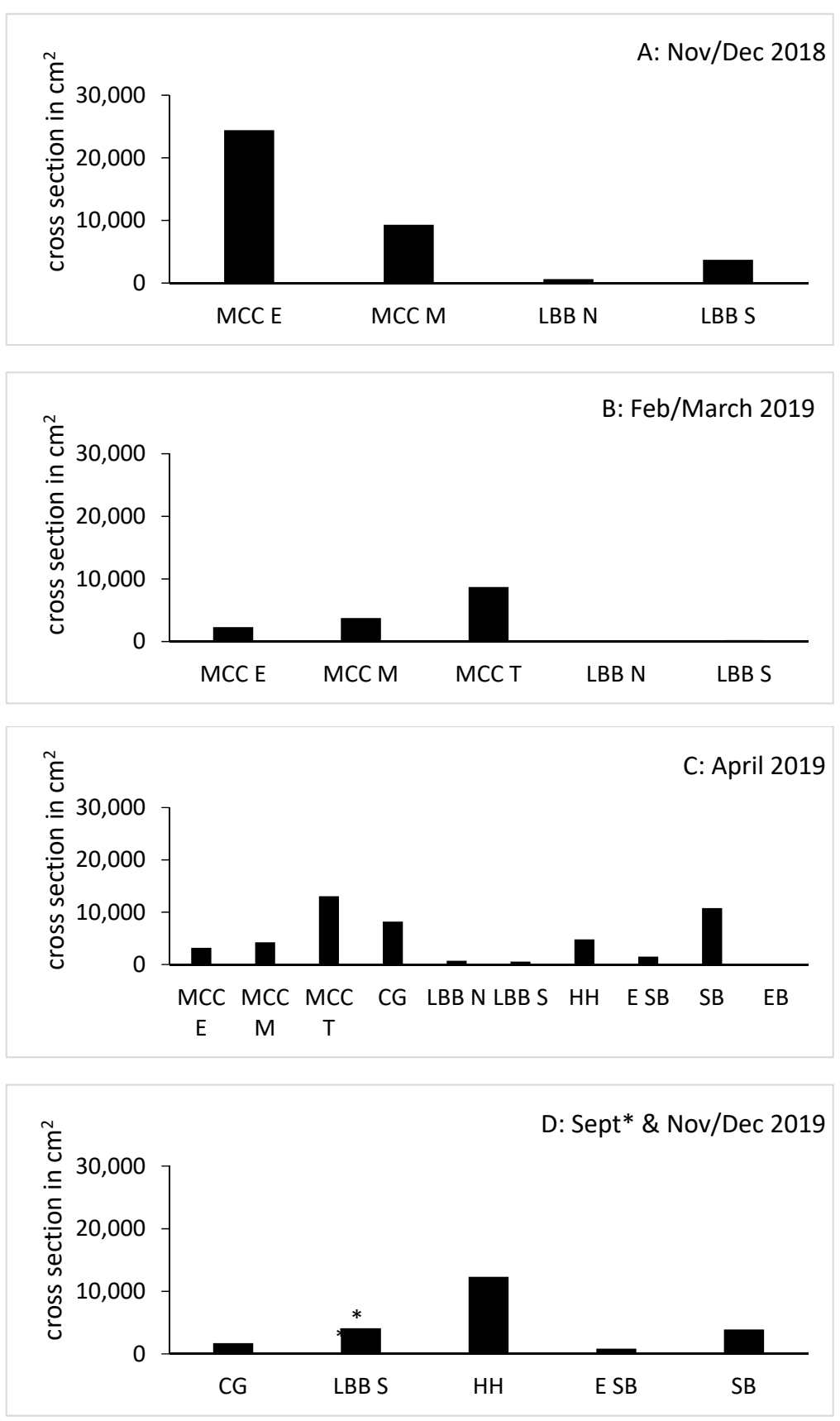

Figure 5. Amount of beached Sargassum found on beaches of South Caicos and Middle Creek Cay. Values represent cross section area perpendicular to the surf line in $\mathrm{cm}^{2}$. Sites are ordered from north to south . MCC = Middle Creek Cay $(\mathrm{T}=$ Tip, $\mathrm{M}=$ Middle, $\mathrm{E}=\mathrm{End}), \mathrm{CG}=$ Coast Guard, $\mathrm{LBB}=$ Long Bay Beach ( $\mathrm{N}$ = north, $\mathrm{S}=$ south), HH = Highland House, ES B = East of Shark Bay, SB = Shark Bay Beach, EB = East Bay Beach. One sample was taken in September 2019, indicated by an * as it is grouped with the samples from November/December 2019.

Most material was found within the first $6 \mathrm{~m}$ from the surf line, with small amounts of dried sargassum present further up the beach (Figure 6, Supplementary Material Figure $\mathrm{S} 1 \mathrm{~A}, \mathrm{~B}, \mathrm{C}, \mathrm{K}, \mathrm{L}, \mathrm{M}, \mathrm{R}, \mathrm{S}, \mathrm{V}, \mathrm{d}, \mathrm{l}, \mathrm{n}, \mathrm{o}, \mathrm{q})$. At many sites, the sargassum was mixed with seagrass (Supplementary Material Figure S1S). On Middle Creek Cay End, the decomposing sargassum seagrass mix that was not in contact with the surf turned into a soil like consistency and contained worms (Supplementary Material Figure S1D) The wet compacted sargassum at Highland House and East of Shark Bay (dark mass seen in Supplementary Material Figure S1l) contained insects that were breaking down the sargassum. On East 
of Shark Bay, the decomposing sargassum accumulated in dense mounds $(1 \mathrm{~m} \times 0.5 \mathrm{~m}$ $\times 1 \mathrm{~m}$ ) in the surf, while at Highland House it formed a dense mat, approximately $1 \mathrm{~m}$ high, on top of rocks, which were also in daily contact with the surf. These mounds were first found in November 2018 and remained until at least June 2019 but were completely absent in November 2019 perhaps removed during a storm event. On some beaches, the accumulation was so high that newly arriving sargassum could not pile up on the beach but accumulated as a mat in the water adjacent to the beach (Supplementary Material Figure S1e,f). In April 2019, Highland House had 2-3 m of floating sargassum accumulate as a mat while Shark Bay had $14.6 \mathrm{~m}$ in April 2019 and $6 \mathrm{~m}$ in November 2019. In autumn 2019, the water at Long Bay Beach North was a very dark color while that on Middle Creek Cay was also slightly brown (Supplementary Material Figure S1A,R,e).

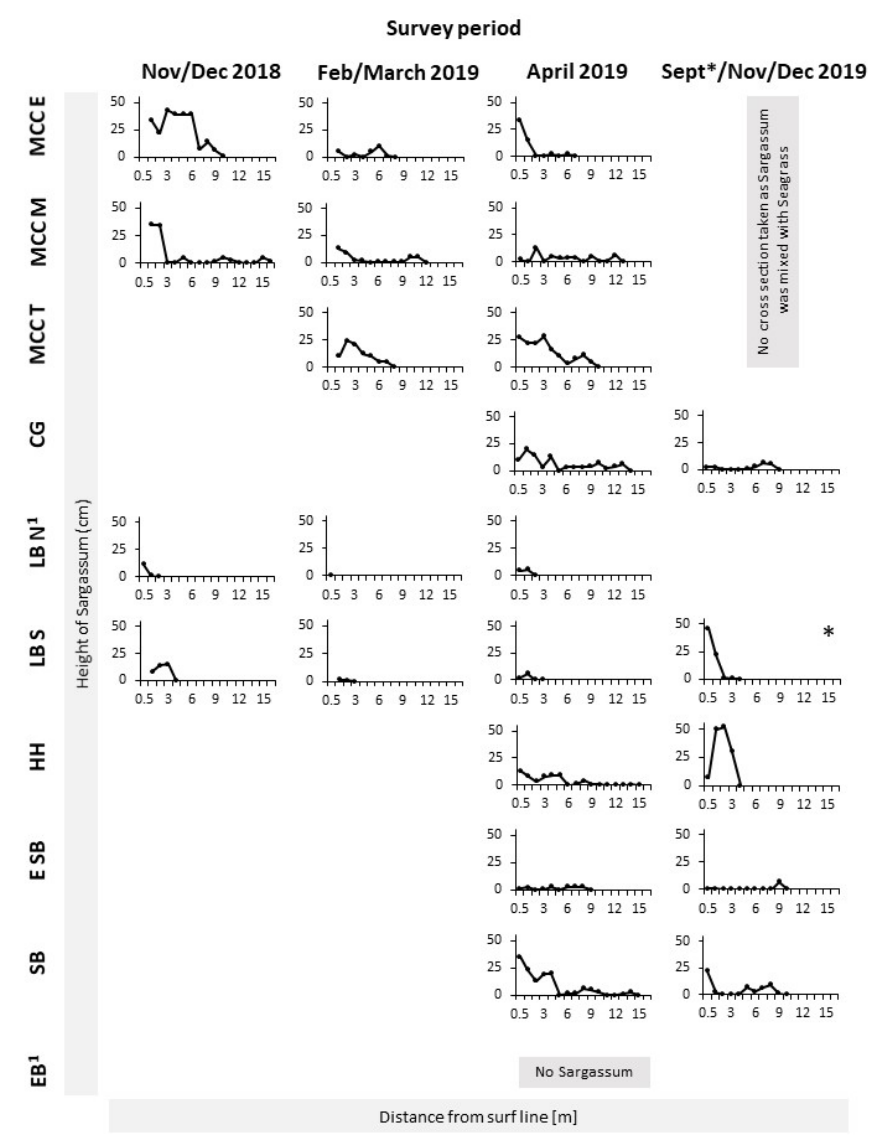

Figure 6. Cross section of the sargassum deposition on the beach. The height of the sargassum measured at the $0.5 \mathrm{~m}$ mark and every $1 \mathrm{~m}$ mark from the surf line to the end of the deposit is visualized in these graphs. Sites are ordered from north to south. MCC = Middle Creek Cay ( $\mathrm{T}=$ Tip, $\mathrm{M}=$ Middle, $\mathrm{E}=$ End), CG = Coast Guard, LBB = Long Bay Beach ( $\mathrm{N}=$ north, $\mathrm{S}=$ south), $\mathrm{HH}=$ Highland House, ES B = East of Shark Bay, SB = Shark Bay Beach, EB = East Bay Beach Sargassum was removed at East Bay Beach and Long Bay Beach North. All other sites had no anthropogenic sargassum removal at any time. One sample was taken in Sept 2019, this one is indicated by an * as it is grouped with the samples from November/December 2019.

Out of the 10 study sites, 9 contained seagrass beds within the first $100 \mathrm{~m}$ from the coast, the only site without any seagrass was Shark Bay Beach. Completely healthy Thalassia testudinum seagrass beds were found throughout the study period at Coast Guard, Highland House and East Bay Beach (Figure 7). The sites located on Middle Creek Cay, on Long Bay Beach and East of Shark Bay all showed signs of recent seagrass die off with a dense field of seagrass stumps being visible (Figure 7, Supplementary Material Figure $\mathrm{S} 1 \mathrm{E}, \mathrm{G}, \mathrm{H}, \mathrm{N}, \mathrm{O}, \mathrm{P}, \mathrm{Q}, \mathrm{X}, \mathrm{c}, \mathrm{d})$. The border between seagrass stumps and healthy T. testudinum 
seagrass was stark and often parallel to the coast (Supplementary Material Figure S1E,N,c). The timeline from Long Bay Beach North shows how the loss of seagrass progressed over time further away from the coast (Figure 7), while the pictures show the progression from stressed unhealthy seagrass (Supplementary Material Figure S1X-Z,a) to seagrass stumps and sandy substrate (Supplementary Material Figure S1b-d). The Middle Creek Cay Middle and Long Bay Beach timelines also show that sand eventually took over areas that were previously covered seagrass stumps (Figure 7). Thalassia testudinum was not able to recolonize the areas lost within the study period. At Long Bay Beach South, a field of Halodule wrightii (Supplementary Material Figure S1h) formed in early 2019 a few meters off the beach in the area that was covered in T. testudinum stumps in late 2018; the rest of the area stayed sandy and bare (Supplementary Material Figure S1i-k). Some of the area lost by T. testudinum on Middle Creek Cay was colonized by cactus tree alga (Caulerpa cupressoides), shaving brush alga (Penicillus capitatus) and Halimeda spp. and T. testudinum (Supplementary Material Figure S1H-J,Q,U). On Middle Creek Cay Middle exposed dead rhizomes were found (Supplementary Material Figure S1P). Sargassum was present on the benthos at the Long Bay Beach and Middle Creek Cay sites in November 2018 and March 2019. It was often found inside T. testudinum seagrass bed (Supplementary Material Figure S1F,Z,a,d) but also forming a thick layer $(5-30 \mathrm{~cm}$ ) on the sediment (Supplementary Material Figure S1g) or being present in a dense nugget-like form (Supplementary Material Figure S1b).

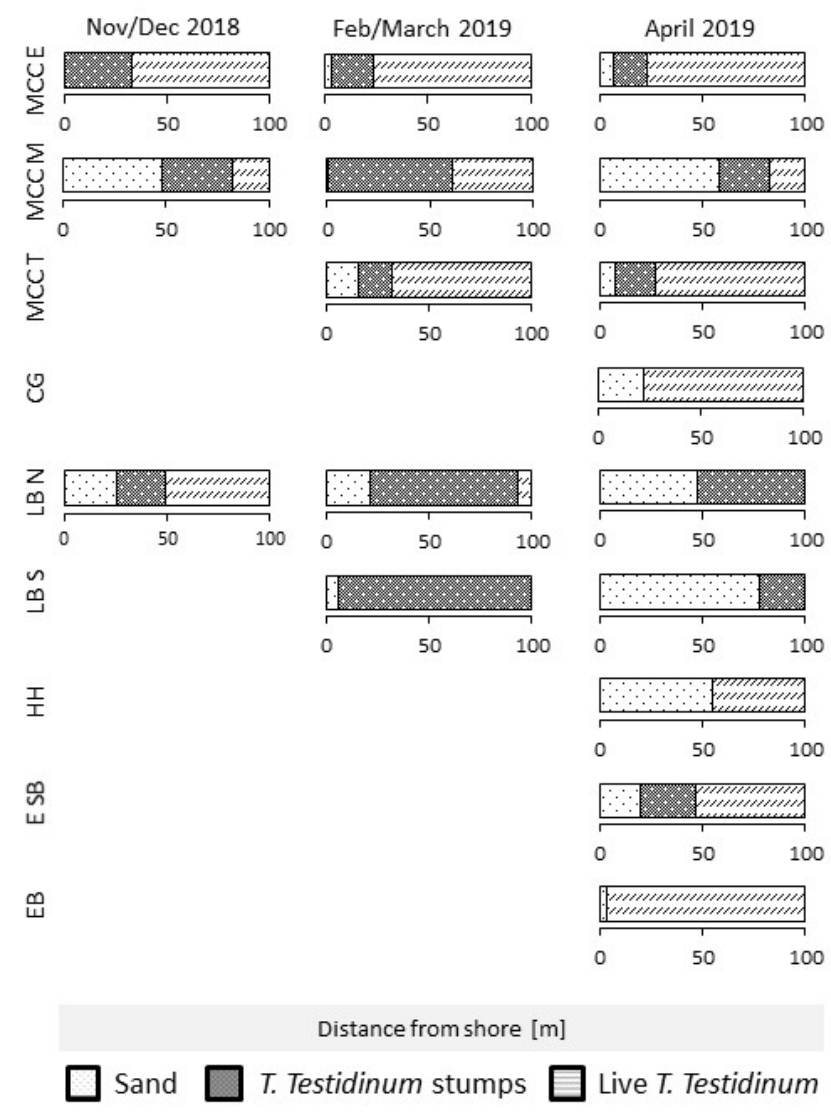

Figure 7. Benthic cover of the near-shore habitats. These graphs show the presence of sand (white with black dots), Thalassia testudinum stumps (black with white dots) and live T. testudinum (hashed) on the first $100 \mathrm{~m}$ from shore for the surveyed sites. The data displayed here is the average of 3 non-permanent transects that were surveyed $5 \mathrm{~m}$ apart. Sites are ordered from north to south. MCC $=$ Middle Creek Cay $(\mathrm{T}=$ Tip, $\mathrm{M}=$ Middle, $\mathrm{E}=$ End $), \mathrm{CG}=$ Coast Guard, $\mathrm{LBB}=$ Long Bay Beach $(\mathrm{N}=$ North, $\mathrm{S}=$ South $), \mathrm{HH}=$ Highland House, ES B = East of Shark Bay, EB = East Bay Beach. Shark Bay Beach naturally has no seagrass cover and was not surveyed. 


\section{Discussion}

\subsection{The Impact of Sargassum on Tourism-Related Businesses}

Focus group discussions and individual responses suggested greater impact was experienced by those offering activities for tourists compared to accommodation providers and food/drink businesses although this may reflect the relative proportions of the different categories sampled. For example, grouping restaurants/bars, accommodation, resorts, and real estate together would result in $68 \%$ reporting impact. Similarly combining activity businesses (travel/boat trips, snorkeling/diving, surface water sports, sports fishing, shore leisure) results in impact on $63 \%$. A UNEP white paper (2021) summarized the impacts found across the regions affected and identified coastal livelihoods, marine transport and navigation, public health as experiencing impact [13]. In the TCI, the impact was felt most strongly by the tourism and fisheries industries, while only minor complaints regarding public health and coastal living were reported.

A similar situation has been reported from Provence, France, where the benthic algae Rugulopteryx okamurae has increased, forming large floating mats that inundate beaches. The main impacts there are on fisheries who have lost catch due to clogged nets, and the hydrogen sulfide $\left(\mathrm{H}_{2} \mathrm{~S}\right)$ produced by the rotting algae causing concern to local residents and water users [33]. In China, a bloom of Ulva prolifera occurred a few weeks before the Olympic sailing competition, leading to extensive clean-up efforts and losses for aquaculture operations [34,35]. Like the sargassum blooms, these green tides occur annually [1].

It was particularly interesting to find that 44 respondents (25 on PLS, 5 GDT and 14 on XCS) said sargassum had always been present, some adding for the whole of their lives but that it was worse some years. This suggests it is not a new phenomenon, as has been suggested but that it is the quantity arriving that has changed. This resonates with finding across the Caribbean that there was a significant increase in 2011, likely to have been caused by changes in winds and currents $[7,14]$. Research carried out into the impact on tourism in Mexico found that operators were encouraging inland, rather than beach, activities [36]; this is not a viable option on TCI.

\subsection{Action Taken to Remove Sargassum}

A total of 44 respondents reported they were removing sargassum (Table 11). Resorts and accommodation providers were removing it from the beach while water sports operators and those engaged in fishing activities were removing floating sargassum when it became entangled in lines or blocked the intakes of jet skis. Most removal was taking place on Providenciales (30) despite this island receiving least sargassum, reflecting the fact that this has the greatest importance for tourism. The most common method was by hand, using rakes and shovels (Table 13) with just three, all on Providenciales, collecting sargassum before it beached; one was using a boom to prevent landing. The CERMES Best practice guide states that is it generally agreed that in-water removal close to shore is preferable to beach collection if locally permitted [37]. This is reflected by the increasing use of containment booms across the region and new innovations in boat based collection systems [38,39]. If beach collection is necessary, then manual removal is preferable for relatively small volumes of sargassum [37].

Disposal after collection varied between simply collecting it into piles on the beach (8), taking it to landfill (7) and burying it (5), with just one example of composting. Burying has been identified as a good option for disposal on wide beaches with low volumes of sargassum, especially those with dunes as it can contribute to beach stability [37]. Frequency of collection and disposal differed widely, reflecting the irregularity of inundations being done on a 'when necessary' basis, reflecting amount of sargassum, arrival of tourists and/or available resource. Only on Martinique is there a requirement for sargassum to be removed from beaches within 3 days [38].

The results presented in this study provide a snapshot of the situation on TCI but provide little information on the amount arriving, being collected, and removed, as few 
records were kept and those that were numbers of bags with no detail regarding bag size or whether the material was wet or dry. The lack of clarity on the amount and regularity of sargassum landings combined with uncertainty regarding chemical composition and potential toxicity, pose a significant barrier to development of a sustainable, commercially viable, end use $[14,40]$.

\subsection{The Interaction between Sargassum and Seagrass Beds}

Two the interviewees raised concern about loss of seagrass habitat, and all fishermen answered that sargassum impacted their business. It was reported that conch yields had decreased. If this was indeed related to the Sargassum influx, it could possibly be due to loss of seagrass habitat for adult and juvenile conch and/or decreased water quality and therefore visibility, about which the freediving fishermen had expressed concern in September 2018 [41]. Dark-colored water, termed 'brown tides' by [42] were observed during the November/December 2018 surveys of Long Bay Beach North and Middle Creek Cay. This was also reported at other locations in August/September 2018, at the peak of the influx that year [41]. Only one of the ten study sites, East Bay Beach, was cleared regularly so had no decomposing sargassum on the beach; all the others had decomposing/decomposed sargassum in the surf line and dried sargassum higher on the beach in at least one survey.

Macroalgae blooms often negatively affect seagrass beds, and surface floating unattached algae have been found to cause the greatest damage [43]. Floating mats of filamentous algae have, for example, led to significantly reduced growth rate and degradation of below-ground tissue for Zostera marina [44]. Complete seagrass bed loss was reported as a result of brown tides on both northern and southern coasts of Quintana Roo, Mexico in 2016 [42]. Specifically, loss of turtle grass (Talassia testudinum) and shore grass (Halodule wrightii), with exposed dead T. testudinum rhizomes, which suggested sediment erosion followed seagrass die-off. The areas formerly occupied by seagrass were colonized by calcareous alga (Halimeda incrassata) and drift/epiphytic algae. These authors also found that drifting masses of sargassum resulted in extremely low dissolved oxygen (DO), reduced $\mathrm{pH}$ and negative $\mathrm{REDOX}$ values (reduction/oxidization potential) and that brown coloration of water, due to organic particles and leachates, had a similar effect but to a lesser extent on these parameters also leading to seagrass bed die off and long-term reduction inwater transparency combined with eutrophication. Other research has recorded beaching of 76 species of fauna during a sargassum brown tide event, including Caribbean spiny lobster (Panulirus argus), commercially important in TCI, and two Snappers (Lutjanidae species) [45]. It is likely these died due to hypoxia due to the deterioration in-water quality. Sargassum leachate has been found to reduce dispersal ability of elkhorn coral (Acropora palmata) larvae [46], an endangered coral species that is present on the coral reefs in front of East Bay Beach and Coast Guard.

The results of the surveys conducted for this research demonstrate sargassum can accumulate and persist on beaches that are not cleared, and this can cause leachate and accumulation of organic matter on the near-shore substrate. Floating masses of sargassum were found to accumulate in the water where there was lack of space for them to beach, for example at Highland House and Shark Bay Beach (April 2019), and Shark Bay Beach and Long Bay Beach South (November 2019). At Long Bay Beach sargassum derived organic matter was observed to have accumulated in the T. testudinum seagrass bed in December 2018, with just the tips of the seagrass blades protruding above it. These tips looked unhealthy while close by non covered seagrasses looked completely healthy. On a repeat visit in February 2019, only stumps of seagrass remained, strongly suggesting it could not survive being covered by sargassum detritus. Sandy planes were observed in areas formerly occupied by T. testudinum stumps, indicating that drift of sandy sediment had replaced the area of seagrass lost. Sparse benthic algae, as well as a small field of $H$. wrightii, were found in some areas from which $T$. testudinum was lost. Recovery of $T$. testudinum beds of the size lost here, up to more than $100 \mathrm{~m}$ off the coast, is likely to take 
decades [42] with significant implication for the fisheries of South Caicos, as these are vital as nurseries and habitat for fished species [25,47,48].

Fisheries are an important component of the economy of TCI and a high proportion of South Caicos residents have fishery-based livelihoods. Sargassum brown tide leachate is likely to lower fishery yields. Fortunately, East Bay, identified as a critical habitat for juvenile lobsters [26], was not observed to be affected, as less sargassum was arriving here than in some other areas and there is daily beach clearance, either with a Barber Surf Rake or manually. The study identifying East Bay as critical habitat, only surveyed one other site surveyed in this study, Coast Guard, so there is a lack of information regarding the significance of other sites. Furthermore more recent information regarding the functional role of the East Bay seagrass beds is lacking. More up-to-date data is clearly required to determine the potential impact of sargassum on seagrass beds, the risk this poses to biodiversity in general and specifically to commercially important fishery species.

\section{Conclusions}

The hotel trade has a vested interested in reassuring potential holiday makers that there is no 'sargassum problem' in TCI, particularly as promotion is based on brochures showing white sand beaches and clear blue water. The results of this research suggest the impact varies from year to year and with season; this unpredictability is a real challenge for management. This research is the second to report seagrass die off during a sargassum brown tides. As these areas support conch (Strombus spp.) and spiny lobster (Panulirus argus), both exported from TCI, as well as commercially important fish, sought after by tourist restaurants, there potentially significant economic implications. Further research should investigate the correlation between brown tides and seagrass bed loss especially to determine which components of the brown tide lead to seagrass loss. Negative effects on tourism and seagrass beds could be avoided by employing booms and near shore, in water, collection of sargassum. However, this would require a change in management practice in TCI. The enhanced quality of sargassum obtained this way, with reduced potential for sand contamination, could enable different valorization pathways and more opportunities for commercial use of sargassum [15].

While this research has attempted to determine the amount of sargassum deposited and seasonality, a more accurate assessment of the available resource for commercial exploitation is required. This paper is part of a wider study intended to inform the potential to identify a sustainable solution to the sargassum inundations on TCI but also determining the relative proportions of the different species and morphotypes of sargassum arriving and their chemical composition. Initial results have been published [49] but detailed analysis of more samples collected in TCI and particularly information on potential toxicity and methane production are awaited as these are essential for any 'sustainable' solution(s) to sargassum inundations can be identified and realized.

Supplementary Materials: The following are available online at https:/ /www.mdpi.com/article/10 .3390 /phycology1020007/s1, Text doc S1: The questionnaire, Figure S1: Photographs of Sargassum inundantion and nearshore seagrass beds, Video S1: Sargassum accumulation composition and height, Video S2: Brown tide event.

Author Contributions: Conceptualization, D.B. and F.E.; Methodology, D.B. and F.E.; Software, Formal Analysis, D.B. and F.E.; Investigation, D.B. and F.E.; Resources, DEFRA DARWIN Plus DPLUS100, School for Field Studies; Data Curation, D.B. and F.E.; Writing-Original Draft Preparation, D.B. and F.E., Writing-Review and Editing, D.B. and F.E.; Visualization, D.B. and F.E., Supervision, D.B. and F.E., Project Administration, D.B., Funding Acquisition, D.B. All authors have read and agreed to the published version of the manuscript.

Funding: This research was funded by DEFRA Darwin Plus grant number DPR7P $\backslash 100059$.

Institutional Review Board Statement: Ethical review and approval were waived for this study, as this was not required. 
Informed Consent Statement: Informed consent was obtained from all subjects involved in the study.

Data Availability Statement: The data presented in this study are available on request from the corresponding author. The data are not publicly available due lack of a repository.

Acknowledgments: This research was funded DEFRA Darwin Plus DPLUS100: in partnership with the Department of Environment and Coastal Resources (DECR), Turks and Caicos Islands (TCI) Government; the University of Greenwich (UofG); the School for Field Studies (SFS), South Caicos, and the Chartered Institute of Ecologists and Environment Managers (CIEEM) Overseas Territory Special Interest Group.

Conflicts of Interest: There are no conflicts of interest.

\section{References}

1. Smetacek, V.; Zingone, A. Green and golden seaweed tides on the rise. Nature 2013, 504, 84-88. [CrossRef] [PubMed]

2. Schell, J.; Goodwin, D.; Siuda, A. Recent Sargassum Inundation Events in the Caribbean: Shipboard Observations Reveal Dominance of a Previously Rare Form. Oceanography 2015, 28, 8-10. [CrossRef]

3. Johnson, D.R.; Ko, D.S.; Franks, J.S.; Moreno, P.; Sanchez-Rubio, G. The Sargassum Invasion of the Eastern Caribbean and Dynamics of the Equatorial North Atlantic. 2012. Available online: http://gcrl.usm.edu/sargassum/docs/Johnson.et.al. Sargassum.event.in.Caribbean.2011.65th.GCFI.Abstract.pdf (accessed on 18 May 2021).

4. Doyle, E.; Franks, J. Sargassum Fact Sheet. Gulf and Caribbean Fisheries Institute. 2015. Available online: http://www. sargassoseacommission.org/storage/documents/GCFI_Sargassum_Fact_Sheet_Doyle_and_Franks_Sept_2015.pdf (accessed on 18 May 2021).

5. Huffard, C.L.; Von Thun, S.; Sherman, A.D.; Sealey, K.; Smith, K.L. Pelagic Sargassum community change over a 40-year period: Temporal and spatial variability. Mar. Biol. 2014, 161, 2735-2751. [CrossRef]

6. Oxenford, H.A. Sargassum Source of Influx and Ecological Aspects. 2018. Available online: https://www.cavehill.uwi.edu/ cermes /getdoc/d17e3c3c-3fc2-422e-bd33-98d585a74f84/2018_Sargassum_Symposium_Presentation_Oxenford.aspx (accessed on 18 May 2021).

7. Wang, M.; Hu, C.; Barnes, B.B.; Mitchum, G.; Lapoite, B.; Montoya, J.P. The great Atlantic Sargassum belt. Science 2019, 365, 83-87. [CrossRef] [PubMed]

8. Johns, E.M.; Lumpkin, R.; Putman, N.F.; Smith, R.H.; Muller-Karger, F.E.; Rueda-Roa, D.T.; Hu, C.; Wang, M.; Brooks, M.T.; Gramer, L.; et al. The establishment of a pelagic Sargassum population in the tropical Atlantic: Biological consequences of a basin-scale long distance dispersal event. Prog. Oceanogr. 2020, 182, 102269. [CrossRef]

9. Coston-Clements, L.; Settle, L.R.; Hoss, D.E.; Cross, F.A. Utilization of the Sargassum Habitat by Marine Invertebrates and Vertebrates: A Review. NOAA Technical Memorandum NMFS-SEFSC-296. 1991. Available online: https://repository.library. noaa.gov/view/noaa/9151 (accessed on 18 May 2021).

10. Laffoley, D.d'A.; Roe, H.S.J.; Angel, M.V.; Ardron, J.; Bates, N.R.; Boyd, I.L.; Brooke, S.; Buck, K.N.; Carlson, C.A.; Causey, B.; et al. The Protection and Management of the Sargasso Sea: The Golden Floating Rainforest of the Atlantic Ocean: Summary Science and Supporting Evidence Case; Sargasso Sea Alliance: Bemuda, UK, 2011; 44p.

11. Lapointe, B.E.; West, L.E.; Sutton, T.T.; Hu, C. Ryther revisited: Nutrient excretions by fishes enhance productivity of pelagic Sargassum in the western North Atlantic Ocean. J. Exp. Mar. Biol. Ecol. 2014, 458, 46-56. [CrossRef]

12. Monroy-Velázquez, L.V.; Rodríguez-Martínez, R.E.; van Tussenbroek, B.I.; Aguiar, T.; Solís-Weiss, V.; ricia Briones-Fourzán, P. Motile macrofauna associated with pelagic Sargassum in a Mexican reef lagoon. J. Environ. Manag. 2019, 252, 109650. [CrossRef]

13. United Nations Environment Programme-Caribbean Environment Programme. Sargassum White Paper-Turning the crisis into an opportunity. In Proceedings of the Ninth Meeting of the Scientific and Technical Advisory Committee (STAC) to the Protocol Concerning Specially Protected Areas and Wildlife (SPAW) in the Wider Caribbean Region, Kingston, Jamaica, 17-19 March 2021.

14. Milledge, J.J.; Harvey, P.J. Golden Tides: Problem or Golden Opportunity? The Valorisation of Sargassum from Beach Inundations. J. Mar. Sci. Eng. 2016, 4, 60. [CrossRef]

15. Desrochers, A.; Cox, S.-A.; Oxenford, H.A.; van Tussenbroek, B. Sargassum Uses Guide: A Resource for Caribbean Researchers, Entrepreneurs and Policy Makers. In Report Funded by and Prepared for the Climate Change Adaptation in the Eastern Caribbean Fisheries Sector (CC4FISH) Project of the Food and Agriculture Organization (FAO); CERMES Technical Report No. 97; Centre for Resource Management and Environmental Studies (CERMES), University of the West Indies, Cave Hill Campus: Bridgetown, Barbados, 2020; p. 172. Available online: https:/ /www.cavehill.uwi.edu/cermes/projects/sargassum/docs/desrochers_et_al_20 20_sargassum_uses_guide_advance.aspx (accessed on 22 April 2021).

16. Cameron, C.; Gatewood, J. Beyond Sun, Sand and Sea: The Emergent Tourism Programme in the Turks and Caicos Islands. J. Herit. Tour. 2008, 3, 55. [CrossRef]

17. Gatewood, J.; Cameron, C. Perceptions of Tourism. Available online: https://www.lehigh.edu/ \{\}jbg1/Perceptions-of-Tourism. pdf (accessed on 1 July 2019).

18. Zuidema, C.; Zuidema, P.; Diko, R.; Dikou, A. To preserve or to develop? East Bay dredging project, South Caicos, Turks and Caicos Islands. J. Coast. Conserv. 2011, 15, 555-563. [CrossRef] 
19. Statistical Office. Turks and Caicos Islands Departing Survey; Department of Economic Planning \& Statistics: South Base, Grand Turk, Turks and Caicos Islands, 2015.

20. Lockhart, K.; De Fontaubert, C.; Clerveaux, W. Fisheries of the Turks and Caicos Islands: Status and Threats; Caribbean Fisheries Institute: San Andres, Colombia, 2007; pp. 66-71. Available online: https://core.ac.uk/download/pdf/19540448.pdf (accessed on 20 October 2021).

21. Proctor, D.; Flemming, L.V. (Eds.) Biodiversity: The UK Overseas Territories; Joint Nature Conservation Committee: Peterborough, UK, 1999; p. 131.

22. Rudd, M.A. Fisheries landings and trade of the Turks and Caicos Islands. Fish. Cent. Res. Rep. 2003, 11, $149-161$.

23. Halls, A.S.; Lewins, R.; Farmer, N. Information systems for co-management of artisanal fisheries. In Field Study 2-Turks E Caicos. Report Prepared for the UK Department for International Development; MRAG Ltd.: London, UK, 1999; p. 115.

24. Béné, C.; Tewfik, A. Fishing effort allocation and fishermen's decision-making process in a multi-species small-scale fishery: Analysis of the conch and lobster fishery in Turks and Caicos Islands. Hum. Ecol. 2001, 29, 157-186. [CrossRef]

25. Baker, S.; Paddock, J.; Smith, A.M.; Unsworth, R.K.; Cullen-Unsworth, L.C.; Hertler, H. An ecosystems perspective for food security in the Caribbean: Seagrass meadows in the Turks and Caicos Islands. Ecosyst. Serv. 2015, 11, 12-21. [CrossRef]

26. Bos, A.R.; Clark, S.; Gore, S. Preliminary observations on habitat use of juvenile Caribbean spiny lobster (Panulirus argus) in South Caicos, Turks \& Caicos Islands. In Proceedings of the Gulf and Caribbean Fisheries Institute, Provideciales, Turks and Caicos Islands, November 2001; Volume 54, pp. 230-240. Available online: http://aquaticcommons.org/13558/1/gcfi_54-17.pdf (accessed on 14 July 2021).

27. Carlson, B. Grand Turk: Its bones are the key to an unexpected past. Times Isl. 2000, 4, 54-57.

28. Fleming, E.H. Swimming against the tide. In Report for TRAFFIC, North America; TRAFFIC North America: Washington, DC, USA, 2001; pp. 133-138. Available online: http://www.earthmind.org/sites/default/files/2001-04-TradeMarineTurtlesNorthernCaribbean.pdf (accessed on 29 October 2021).

29. Cullen-Unsworth, L.C.; Nordlund, L.M.; Paddock, J.; Baker, S.; McKenzie, L.J.; Unsworth, R.K. Seagrass meadows globally as a coupled social-ecological system: Implications for human wellbeing. Mar. Pollut. Bull. 2014, 83, 387-397. [CrossRef] [PubMed]

30. Sakshaug, J.W.; Hülle, S.; Schmucker, A.; Liebig, S. Exploring the Effects of Interviewer- and Self-Administered Survey Modes on Record Linkage Consent Rates and Bias. Surv. Res. Methods 2017, 11, 171-188. [CrossRef]

31. Thomas, L.; MacMillan, J.; McColl, E.; Hale, C.; Bond, S. Comparison of focus group and individual interview methodology in examining patient satisfaction with nursing care. Soc. Sci. Health 1995, 1, 206-219.

32. Acocella, I. The focus groups in social research: Advantages and disadvantages. Qual. Quant. 2011, 46, 1125-1136. [CrossRef]

33. Ruitton, S.; Blanfuné, A.; Boudouresque, C.F.; Guillemain, D.; Michotey, V.; Roblet, S.; Verlaque, M. Rapid Spread of the Invasive Brown Alga Rugulopteryx okamurae in a National Park in Provence (France, Mediterranean Sea). Water 2021, 13, 2306. [CrossRef]

34. Ye, N.-H.; Zhang, X.-W.; Mao, Y.-Z.; Liang, C.-W.; Xu, D.; Zou, J.; Zhuang, Z.-M.; Wang, Q.-Y. 'Green tides' are overwhelming the coastline of our blue planet: Taking the world's largest example. Ecol. Res. 2011, 26, 477-485. [CrossRef]

35. Liu, D.; Keesing, J.K.; He, P.; Wang, Z.; Shi, Y.; Wang, Y. The world's largest macroalgal bloom in the Yellow Sea, China: Formation and implications. Estuar. Coast. Shelf Sci. 2013, 129, 2-10. [CrossRef]

36. Casas-Beltrán, D.A.; Gallaher, C.M.; Yac, E.H.; Moreno, K.F.; Voglesonger, K.; Leal-Bautista, R.M.; Lenczewski, M. Seaweed Invasion! Temporal Changes in Beach Conditions Lead to Increasing Cenote Usage and Contamination in the Riviera Maya Diego. Sustainability 2020, 12, 2474. [CrossRef]

37. Hinds, C.; Oxenford, H.; Cumberbatch, J.; Fardin, F.; Doyle, E.; Cashman, A. Golden Tides: Management Best Practices for Influxes of Sargassum in the Caribbean with a Focus on Clean-up. 2016. Available online: https://www.cavehill.uwi.edu/ cermes/getdoc/123bf91c-1565-414d-8e21-e59fb6f7ca2d/cermes_sargassum_management_brief_2016_08_24.aspx (accessed on 5 October 2021).

38. Van der Plank, S.; Corbett, J.; Cumberbatch, J.; Thomas, B.; Tompkins, E. Management of Sargassum influxes in the Caribbean: National and regional governance of a transboundary marine species (Vol. 2964). In SARTRAC Working Paper 1, Teleconnected Sargassum Risks across the Atlantic: Building Capacity for Transformational Adaptation in the Caribbean and West Africa (SARTRAC), ESRC Reference: ES/T00294/1; 2020. Available online: www.sartrac.org (accessed on 29 October 2021).

39. Gray, L.A.; León, A.G.B.; Rojas, F.E.; Veroneau, S.S.; Slocum, A.H. Caribbean-Wide, Negative Emissions Solution to Sargassum spp. Low-Cost Collection Device and Sustainable Disposal Method. Phycology 2021, 1, 49-75. [CrossRef]

40. Oxenford, H.A.; Cox, S.A.; van Tussenbroek, B.I.; Desrochers, A. Challenges of Turning the Sargassum Crisis into Gold: Current Constraints and Implications for the Caribbean. Phycology 2021, 1, 27-48. [CrossRef]

41. Center for Marine Resource Studies Staff. Personal communication, 2019.

42. van Tussenbroek, B.I.; Arana, H.A.H.; Rodríguez-Martínez, R.E.; Espinoza-Avalos, J.; Canizales-Flores, H.M.; González-Godoy, C.E.; Collado-Vides, L. Severe impacts of brown tides caused by Sargassum spp. on near-shore Caribbean seagrass communities. Mar. Pollut. Bull. 2017, 122, 272-281. [CrossRef] [PubMed]

43. Thomsen, M.; Wernberg, T.; Engelen, A.; Tuya, F.; Vanderklift, M.; Holmer, M.; McGlathery, K.; Arenas, F.; Kotta, J.; Silliman, B. A Meta-Analysis of Seaweed Impacts on Seagrasses: Generalities and Knowledge Gaps. PLoS ONE 2012, 7, e28595. [CrossRef] [PubMed]

44. Holmer, M.; Nielsen, R.M. Effects of filamentous algal mats on sulfide invasion in eelgrass (Zostera marina). J. Exp. Mar. Biol. Ecol. 2007, 353, 245-252. [CrossRef] 
45. Rodríguez-Martínez, R.E.; Medina-Valmaseda, A.E.; Blanchon, P.; Monroy-Velázquez, L.V.; Almazán-Becerril, A.; Delgado-Pech, B.; García-Rivas, M.C. Faunal mortality associated with massive beaching and decomposition of pelagic Sargassum. Mar. Pollut. Bull. 2019, 146, 201-205. [CrossRef]

46. Antonio-Martínez, F.; Henaut, Y.; Vega-Zepeda, A.; Cerón-Flores, A.I.; Raigoza-Figueras, R.; Cetz-Navarro, N.P.; Espinoza-Avalos, J. Leachate effects of pelagic Sargassum spp. on larval swimming behavior of the coral Acropora palmata. Sci. Rep. 2020, 10, 3910. [CrossRef] [PubMed]

47. Claydon, J.A.B.; Kroetz, A.M. The distribution of early juvenile groupers around South Caicos, Turks and Caicos Islands. In Proceedings of the 60th Gulf and Caribbean Fisheries Institute, Punta Cana, Dominican Republic, 5-9 November 2008; Volume 60, pp. 345-350.

48. Hesse, K.O. Movement and migration of the queen conch, Strombus gigas in the Turks and Caicos Islands. Bull. Mar. Sci. 1979, 29, 303-311.

49. Milledge, J.J.; Maneein, S.; Arribas López, E.; Bartlett, D. Sargassum Inundations in Turks and Caicos: Methane Potential and Proximate, Ultimate, Lipid, Amino Acid, Metal and Metalloid Analyses. Energies 2020, 13, 1523. [CrossRef] 